\title{
Weather requirements and rain forecast to time fungicide application for Fusarium head blight control in wheat
}

\author{
Ricardo Brustolin $^{1}$, Sandra Maria Zoldan ${ }^{1,2}$, Erlei Melo Reis ${ }^{1,2}$, Tiago Zanatta ${ }^{1}$, Marcelo Carmona $^{3}$
}

\begin{abstract}
${ }^{1}$ Faculdade de Agronomia e Medicina Veterinária, Universidade de Passo Fundo, Passo Fundo, RS - Brazil; ${ }^{2}$ Fellow of CNPq; ${ }^{3}$ Facultad de Agronomia, Universidad de Buenos Aires - Argentina

Autor para correspndência: Ricardo Brustolin. (ricardo.brustolin@bol.com.br)

Data de chegada: 21/11/2012. Aceito para publicação em: 01/10/2013.
\end{abstract}

\section{ABSTRACT}

Brustolin, R; Zoldan, S. M.; Reis, E. M.; Zanatta, T.; Carmona, M. Weather requirements and rain forecast to time fungicide application for Fusarium head blight control in wheat. Summa Phytopathologica, v.39, n.4, p.248-251, 2013.

The aim of this study was to determine the minimum conditions of wetness duration and mean temperature required for Fusarium head blight infection in wheat. The weather model developed by Zoldan (2008) was tested in field experiments for two wheat cultivars grown in 2005 (five sowing dates) and 2006 ( plots with three replicates. The disease was assessed according to head incidence (HI), spikelet incidence (SI), and the interaction between these two methods was called head blight severity (HBS). Starting at the beginning of anthesis, air temperature and head wetness duration were daily recorded with an automatic weather station. With the combination of these two factors, a weather favorability table was built for the disease occurrence. Starting on the day of flowering beginning ( 1 - 5\% fully exserted anthers), the sum of daily values for infection favorability (SDVIF) was calculated by means of a computer program, according to Zoldan (2008) table. The initial symptoms of the disease were observed at $3.7 \%$ spikelet incidence, corresponding to 2.6 SVDFI. The infection occurs in wheat due to rainfall which results in spike wetting of $>61.4 \mathrm{~h}$ duration. Rainfall events forecast can help time fungicide application to control FHB. The name of this alert system is proposed as UPF-scab alert.

Additional keywords: Triticum aestivum, Gibberella zeae, Fusarium graminearum, scab, disease forecasting.

\section{RESUMO}

Brustolin, R.; Zoldan, S. M.; Reis, E. M.; Zanatta, T.; Carmona, M. Requerimentos ambientais e previsão de chuva como indicador do momento para aplicação de fungicidas no controle da Giberela em trigo. Summa Phytopathologica, v.39, n.4, p.248-251, 2013.

O objetivo deste trabalho foi determinar as condições mínimas de duração do molhamento em função da temperatura requeridas para a infecção de giberela em trigo. O modelo climático desenvolvido por Zoldan (2008) foi testado em experimentos de campo com duas cultivares de trigo cultivadas em 2005 (cinco épocas de semeadura) e 2006 (seis épocas de semeadura) em parcelas de $10 \mathrm{~m}^{2}$ com três repetições. A doença foi avaliada pela incidência em espigas (IE), incidência em espiguetas (Ie) e pela interação desses dois métodos e considerado como severidade. A partir do início da antese, a temperatura do ar e a duração do molhamento das espigas foram monitorados diariamente com uma estação meteorológica automática. Com a combinação desses dois fatores, foi elaborada uma tabela de favorabilidade do ambiente para ocorrência da doença. A partir do dia do início da floração (1-5\% anteras completamente expostas) a soma dos valores diários para favorabilidade para a infecção (SVDFI) foi calculada com um programa de computador, de acordo com a tabela de Zoldan (2008). Os sintomas iniciais da doença foram observados com uma incidência em espigas de 3,7\% e correspondendo 2,6 de SVDFI. A infecção do trigo ocorre em função de chuvas que resultam no molhamento das espigas $>61.4 \mathrm{~h}$ de duração. A previsão da ocorrência de chuvas pode auxiliar na indicação do momento indicador da aplicação de fungicidas visando ao controle da giberela. Propõem-se o nome do sistema de aviso de UPF-scab-alert.

Palavras-chave adicionais: Triticum aestivum, Gibberella zeae, Fusarium graminearum, fusariose, previsão da doença.

Fusarium head blight (FHB), or wheat scab, caused by Gibberella zeae Petch (anamorph = Fusarium graminearum $(\mathrm{Fg})$ Schwabe), is a floral infectious disease. For wheat, initial FHB was long reported to occur via the anthers $(2,11,12)$. In the 1970 s, the relationship between FHB and anthesis was associated with the presence of high concentrations of the molecule stimulants betaine and choline (16). However, a subsequent study by Engle et al. (6) indicated that endogenous compounds in floral parts might not be associated with FHB infection.
FHB occurrence, linked to mycotoxin contamination in infected grains, is widespread, reducing the yield and grain quality in wheat growing areas worldwide $(7,8,14,17)$. Severe epidemics often occur when favorable weather conditions for fungi infection coincide with vulnerable crop growth stages $(1,8)$. Infection occurrence and intensity depend on the spike wetness duration and the temperature during and after flowering (17). The dependence on weather factors and the disease sporadic manifestation have determined the need to better understand the weather requirements for this infection. 
FHB has proven a difficult disease to manage because of limitations in control measures $(8,14)$. Cultural (crop rotation, seeding time), chemical, biological and genetic control has been used to reduce its spread and severity. Control by using resistant cultivars is difficult as their genetic resistance is insufficient to reduce the damage to subeconomic levels when weather conditions are favorable. Fungicide application can be an alternative control method. However, despite the availability of effective fungicides (3), problems such as insufficient cover of infection sites like anthers have persisted, resulting in a maximum $48.2 \%$ incidence control, $48.9 \%$ severity control, and $73.6 \%$ scab index when application was at the beginning of flowering (5).

Several reports have shown strong association of FHB epidemics with wet weather during and after anthesis in winter cereals $(1,8,14$, 18). Wheat is susceptible to infection from the flowering (anthesis) stage to the soft dough stage of kernel development (8).

FHB occurs more frequently in the wheat regions of hot and humid weather, especially where rainfall is high and spike wetness duration is $>48$ hours $(1,11,12)$. Such a wetting duration is the result of rain instead of dew. Therefore, rain is the wetting source of spikes. According to Moschini \& Fortugno (9), FHB requires two consecutive days of rain to occur, the first day with $\geq 0.2 \mathrm{~mm}$, $\mathrm{RH}>81$, and $\geq 78$ on the second day. No rain, no wetting and no infection.

Not all rain can result in head wetness duration $>48 \mathrm{~h}$, and on the other side, heavy rain does not relate to the duration of wheat heads wetting. Thus, whenever there is rain, regardless of its volume, resulting in wetness $>48$ hours, there will be infection. Thus, one can infer that FHB infection is a rain-dependant disease.

Therefore, rain required for wetting wheat spikes can be a useful tool to forecast future FHB occurrence.

The aims of this study were to determine, under field conditions, the minimum head wetness period duration and temperature for FHB onset and the likelihood to use rainfall forecast to time fungicide application for disease management.

\section{MATERIALAND METHODS}

\section{Field experiments}

The experiments were conducted in the experimental field of University of Passo Fundo (52 24' 24" S; 28 $18^{\circ}$ ' 46" W, 680m a.s.1.), during the 2005 and 2006 wheat growing seasons. In 2005, treatments consisted of five sowing dates and three replicates for two wheat cultivars (CEP 0059 and BRS 179), while in 2006 there were six sowing dates (Tables 1 and 2). Sowing was carried out at every 710 days (Tables 1 and 2). This totaled 22 combinations of phenological stages and weather conditions.

Each $10 \mathrm{~m}$ x $1 \mathrm{~m}$ plot consisted of five rows at $0.2 \mathrm{~m}$ apart; sowing was done directly onto soybean residues with no-till drilling. All procedures followed the guidelines specified for wheat (6), except for disease control in the leaves, which received two applications of tebuconazole (Folicur $250 \mathrm{CE}$ ) at $0.6 \mathrm{~L} / \mathrm{ha}$ : the first application at tillering and the second one at booting.

\section{Assessments}

In this study, we consider "beginning of heading" when 1 to $5 \%$ of plants have completely exposed the heads; "beginning of anthesis or flowering" when 1 to $5 \%$ of heads exposed their first anther; "duration of flowering" (DF) is the number of days from emergence of the first anther fully exserted (hanging outside by its filament); and "day of
Table 1. Sowing and assessment dates during the 2005 season.

\begin{tabular}{llll}
\hline \multirow{2}{*}{ Sowing date } & \multicolumn{3}{c}{ Evaluation } \\
\cline { 2 - 4 } & First $(\mathbf{H I})$ & Second $(\mathbf{H I})$ & Third $($ HS/SI) \\
\hline $06 / 25 / 05$ & $10 / 18 / 05$ & $10 / 21 / 05$ & $10 / 27 / 05$ \\
& and $10 / 19 / 05$ & & and $10 / 29 / 05$ \\
$07 / 02 / 05$ & $10 / 13 / 05$ & $10 / 20 / 05$ & $11 / 04 / 05$ \\
$07 / 11 / 05$ & $10 / 22 / 05$ & $11 / 10 / 05$ & $11 / 11 / 05$ \\
$07 / 20 / 05$ & $10 / 30 / 05$ & $11 / 11 / 05$ & $11 / 14 / 05$ \\
$07 / 28 / 05$ & $11 / 01 / 05$ & $11 / 18 / 05$ & $11 / 21 / 05$ \\
& and $11 / 03 / 05$ & & \\
\hline HI: head incidece; HS: head severity or spikelet incidence (SI).
\end{tabular}

HI: head incidence; HS: head severity or spikelet incidence (SI).

Table 2. Sowing and assessment dates during the 2006 season.

\begin{tabular}{|c|c|c|c|}
\hline \multirow{3}{*}{$\begin{array}{l}\text { Sowing } \\
\text { date }\end{array}$} & \multicolumn{3}{|c|}{ Evaluation } \\
\hline & \multirow{2}{*}{ First (HI) } & \multicolumn{2}{|c|}{ Second $(\mathrm{HI})$} \\
\hline & & (HI) & (HS/SI) \\
\hline $05 / 29 / 06$ & Frost & - & - \\
\hline 06/07/06 & Frost & - & - \\
\hline $06 / 19 / 06$ & $10 / 10 / 06$ & $10 / 27 / 06$ & $10 / 27 / 06$ \\
\hline $06 / 30 / 06$ & 10/17/06-BR & $11 / 03 / 06$ & $11 / 03 / 06$ \\
\hline & 2310/23/06-Pampeano & & \\
\hline 07/11/06 & $10 / 31 / 06$ & $11 / 07 / 06$ & $11 / 07 / 06$ \\
\hline $07 / 21 / 06$ & - & $11 / 07 / 06$ & $11 / 07 / 06$ \\
\hline
\end{tabular}

$\mathrm{HI}=$ head incidence; HS: head severity or spikelet incidence (SI).

(-) no assessment performed.

symptoms onset" when head incidence (HI) reached 1 to $5 \%$, detected by daily visual inspection.

In 2005, infection was assessed at three times (Table 1). The first and second evaluations were made for plants in the second row of each plot, quantifying the HI after symptom onset. In the third evaluation, 100 main stem ears were randomly collected along $5 \mathrm{~m}$ of the same row, and the number of healthy and diseased spikelets at the moment of greatest contrast between them were determined.

In 2006, the disease was also assessed at three times, except in the case of the fourth sowing date, when only two assessments were made due to late symptom onset (Table 2). One hundred heads, from each cultivar, were collected and in the first and second evaluations, the percentage of HI was determined, while disease severity, measured as spikelet incidence (SI), was only recorded in the second assessment.

Pathogen infection always occurred under natural conditions.

\section{Weather monitoring}

The interaction table (Table 3) between temperature, head wetness duration and resulting FHB intensity, used in the warning system, was developed by Zoldan (18). Meteorological data were recorded with an Aura ${ }^{\circledR}$ equipment (www. elomed.com.br). In the validation work, daily values of infection favorability (DVIF) for $F$. graminearum in wheat spikelets were estimated from the observed values of temperature during the wetting period and head wetness duration (HWD) from the start of anthesis to grain dough stage.

DVIF data were compared with HI values from field evaluations to identify the SDVIF corresponding to the day of infection onset. 
Table 3. Interactions between air temperature (at $3^{\circ} \mathrm{C}$ intervals) and head wetness duration (HWD) which give different daily values of infection favorability (DVIF) for Gibberella zeae in wheat spikelets.

\begin{tabular}{|c|c|c|c|c|c|}
\hline \multirow{4}{*}{ DVIF } & $\mathbf{0}^{\mathrm{z}}$ & 1 & 2 & 3 & 4 \\
\hline & \multicolumn{5}{|c|}{ T $\left({ }^{\circ} \mathrm{C}\right)$ Spikelet incidence $(\%)$} \\
\hline & $\mathbf{0}$ & $1-15$ & $16-40$ & 41-60 & $>60$ \\
\hline & \multicolumn{5}{|c|}{ HWD (h) } \\
\hline $10-12$ & $<12$ & $>13$ & - & - & - \\
\hline $13-15$ & $<8$ & $9-28$ & $>29$ & - & - \\
\hline $16-18$ & $<6$ & $7-23$ & $24-42$ & $>43$ & - \\
\hline $19-21$ & $<6$ & $7-21$ & $22-36$ & $>37$ & - \\
\hline $22-24$ & $<5$ & $6-20$ & $21-34$ & $35-45$ & $>46$ \\
\hline $25-27$ & $<5$ & $6-20$ & $21-33$ & $34-44$ & $>45$ \\
\hline $28-30$ & $<5$ & $6-20$ & $21-33$ & $34-45$ & $>46$ \\
\hline $31-33$ & $<6$ & $7-22$ & $23-37$ & $>38$ & - \\
\hline $34-35$ & $<8$ & $9-29$ & $>30$ & - & - \\
\hline
\end{tabular}

${ }^{\mathrm{z}} 0$, no infection; 1,1 to $15 \% ; 2,16$ to $40 \% ; 3,41$ to $60 \%$ and $4,>60 \%$ spikelet incidence; (-) Incidence not apparent (17).

\section{RESULTS}

In the different sowing dates, different weather conditions occurred at flowering, simulating different wheat crop seasons. The disease occurred in both seasons and in all sowing dates. Disease intensity was associated with anthesis and cultivar reaction, but the cultivar tolerance level was disregarded in the validation system.

The experiments simulated 22 growing seasons, providing results that included different weather conditions and flowering times. Gibberella zeae infection did not depend on the amount of rainfall, but on the temperature and wetness duration. The occurrence and the severity of FHB were directly related to the interaction between temperature and HWD as previously shown by Andersen (1). FHB occurred at different intensities in the two seasons, for all varieties and sowing dates.

For the first and second sowing times, there were no weather conditions for disease onset (Table 4)

The weather conditions that determined the lowest FHB incidence were HWD of $64.1 \mathrm{~h}$ and mean air temperature of $16.9^{\circ} \mathrm{C}$ during the wetting period. This environmental condition resulted in $3.4 \%$ head incidence, the lowest detected throughout the study (Table 4).

The weather conditions that determined the highest $\mathrm{HI}$ were those favorable for the disease development (Table 4).

\section{DISCUSSION}

In dry seasons, such as in 1999, when the period from wheat flowering to ripening coincided with a La Niña phenomenon, FHB occurred at low intensity. Rather higher disease incidence was observed in 2000 season with an El Niño phenomenon, when the conditions of temperature and heads wetness duration were favorable for infection. The likelihood to predict these phenomena is very important for management decisions regarding chemical control of FHB.

Regarding head wetness duration, FHB infection needed the occurrence of rain, since dew which was a short wetness duration phenomenon was not sufficient. Rainfall prediction is increasingly accurate and has become a useful tool in FHB management due to its relationship with head wetting duration (www.cptec.inpe.br/).

This worldwide FHB re-emergence is believed to be driven by changes in climate and agronomic practices such as no-till $(7,8)$. The maintenance of crop residues on the soil surface contributes to pathogen survival and high inoculum production between growing seasons, ensuring thus the presence of abundant inoculum during/ after the flowering of winter cereals (13). Gibberela zeae survives well in crop residue, and under the right weather conditions for spike wetness duration and temperature during and after anthesis, the susceptible wheat varieties can be infected by the pathogen. The determining factor for FHB occurrence is the existence of favorable conditions (17) for infection during the period of wheat susceptibility (presence of fully exserted anthers). Periods of warm weather with persistent head wetness are key conditions for FHB epidemics.

FHB more frequently occurs in the wheat regions of hot and humid weather, especially where rainfall is high and spike wetness duration is $>48$ hours $(1,11,12)$. Such a wetting duration is the result of rain instead of dew.

Therefore, rain is the wetting source for spike infection. According to Moschini \& Fortugno (10), FHB requires two consecutive days of rain, the first day with $\geq 0.2 \mathrm{~mm}, \mathrm{RH}>81$, and $\geq 78$ on the second day. This combination was called the critical period. No rain, no wetting period duration for wheat head infection.

Not all rain can result in head wetness duration $>48 \mathrm{~h}$, and on the other side, heavy rain does not relate to the duration of wheat head wetting. Thus, whenever there is rain, regardless of its volume, resulting in wetness $>48$ hours, there will be infection.

Therefore, rain required for wetting the spikes of wheat can be a useful tool to forecast future FHB occurrence.

Our proposal is based on rain forecast, which has the advantage of its simplicity to obtain information and improve the accuracy in indicating the time for fungicide application. Rain has been forecasted 48 to $72 \mathrm{~h}$ beforehand by CPTEC/INPE (www.cptec.inpe.br/). Thus,

Table 4. FHB incidence in wheat heads as a function of temperature during the wetting period and wetness duration and the corresponding DVIF values.

\begin{tabular}{|c|c|c|c|c|c|c|c|c|c|c|}
\hline $\begin{array}{c}\text { Sowing } \\
\text { date }\end{array}$ & Cultivar & $\begin{array}{l}\text { Beginning } \\
\text { of anthesis } \\
\text { (date) }\end{array}$ & $\begin{array}{c}\text { Beginning } \\
\text { of wetting } \\
\text { period (date) }\end{array}$ & $\begin{array}{c}\text { End of } \\
\text { wetting } \\
\text { period (date) }\end{array}$ & DVIF & $\begin{array}{c}\text { HWD } \\
\text { (hour) }\end{array}$ & $\begin{array}{c}\text { Mean } \\
\text { temperature } \\
\left({ }^{\circ} \mathrm{C}\right)\end{array}$ & $\begin{array}{c}\text { Symptom } \\
\text { onset } \\
\text { (date) }\end{array}$ & $\begin{array}{c}\text { HI } \\
\text { Assessment } \\
\text { (date) }\end{array}$ & $\begin{array}{c}\text { HI } \\
(\%)\end{array}$ \\
\hline $3^{\text {rd }}$ & CEP 0059 & $06 /$ Oct & $06 / \mathrm{Oct}$ & $09 /$ Oct & 3 & 61.0 & 16.2 & $20 / \mathrm{Oct}$ & $22 / \mathrm{Oct}$ & 1.7 \\
\hline $4^{\text {th }}$ & CEP 0059 & 14/Oct & $14 / \mathrm{Oct}$ & $18 /$ Oct & 2 & 94.5 & 14.9 & $22 / \mathrm{Oct}$ & $30 / \mathrm{Oct}$ & 5.1 \\
\hline $5^{\text {th }}$ & CEP 0059 & $20 /$ Oct & $21 /$ Oct & $23 /$ Oct & 3 & 50.5 & 18.2 & $29 /$ Oct & 01/Nov & 3.2 \\
\hline $6^{\text {th }}$ & BRS 179 & $22 / \mathrm{Oct}$ & $21 / \mathrm{Oct}$ & $23 / \mathrm{Oct}$ & 3 & 50.5 & 18.2 & 29/Oct & 01/Nov & 3.6 \\
\hline Mean & - & - & - & - & 2.7 & 64.1 & 16.9 & - & - & 3.4 \\
\hline
\end{tabular}

DVIF = daily values for infection favorability, after Table 3; HWD = head wetness duration; HI = head incidence. FHB= Fusarium head blight 
rain keeping heads wet for at least $64.1 \mathrm{~h}$ and at a mean air temperature of $16.9^{\circ} \mathrm{C}$ results in FHB infection.

Efforts to develop models or disease forecasting systems to contribute to effective disease management have been stimulated ( 5 , 9, 10, www.embrapa trigo sisalert).

Therefore, efficient fungicide should be applied when wheat field is at flowering and before rainfall according to forecast. Under no rain forecast, no fungicide should be sprayed. Unfortunately, we still do not have an accurate prediction of the amount or duration of wetness resulting from a forecasted rain.

The employment of disease prediction models may be useful to predict the disease intensity and generate control recommendations but further study is necessary to validate them before correct use can be guaranteed. Thus, the model validation and evaluation is necessary before FHB incidence can be reliably predicted in the field, leading to increased ability of farmers to achieve good disease management by correctly timing chemical spraying.

\section{REFERENCES}

1. Andersen, A. L. The development of Gibberella zeae head blight of wheat. Phytopathogy, St Paul, v. 38, p. 595-611, 1948.

2. Arthur, J. C. Wheat scab. Indiana Agricultural Experimental Station, St. Paul, v. 36, p.192-232, 1981

3. Avozani, A.; Tonin, R. B.; Reis, E. M.; Camera, J.; Ranzi, C. Sensibilidade de Fusarium graminearm a fungicidas, in vitro. In Seminário sobre Giberela em Cereais de Inverno: coletânea de trabalhos/organizador Erlei Melo Reis; Passo Fundo; vol. 1; Ed Berthier; p. 235252, 2011.

4. Casa, R. T.; Bogo, A.; Moreira, E. N.; Kuhnem, Jr. P. Timing of application and fungicide performance in the control of Fusarium head bligth in wheat. Ciência Rural, Santa Aaria, v.37, n.6, p. 1558-1563. 2007.

5. Del Ponte, E.M.; Fernandes, J.M.C.; Pierobom, C.R.; Bergstrom, G.C. Giberela do trigo - aspectos epidemiológicos e modelos de previsão. Fitopatologia Brasileira, Brasília, DF, v. 29, p.587$605,2004$.

6. Engle, J.S.; Lipps, P.E.; Grahan, T.L.; Boehm, M.J. Effects of choline, betaine, and wheat floral extracts on growth of Fusa- rium graminearum. Plant Disease, St. Paul, v. 88, p. 175-180, 2004.

7. McMullen, M.; Bergstrom, G.; Wolf, E. D.; Dill-Macky, R.; Hershman, D.; Shaner, G.; Van Sanford, D. A unified effort to fight an enemy of wheat and barley: Fusarium head blight. Plant Disease, St. Paul (in press, 2012)

8. McMullen, M.; Jones, R. Gallemberg, D. Scab of wheat and barley: A re-emerging disease of devastating impact. Plant Disease, St Paul, v. 81, p.1340-1348, 1997.

9. Moschini, R.; Fortugno, C. Predicting wheat head blight incidence using models based on meteorological factors in Pergamino, Argentina. European Journal of Plant Patholology, New York, v. 102, p. 211-218, 1996.

10. Moschini, R. C.; Pioli, R.; Carmona, M.; Sacchi, O. Empirical Prediction of Wheat Head Blight in the Northern Argentinean Pampas Region. Crop Science, Madison, v.41 p. 1541-1545, 2001.

11. Parry, D. W.; Jenkinson, P.; Mcleod, L. Fusarium ear blight (scab) in small grain cereals - a review. Plant Pathology, New Jersey, v. 44, p. 207-238, 1995.

12. Pugh, G.W.; Johann, H.; Dickson, J.G. Factors affecting infection of wheat heads by Gibberella saubinetii. Journal of Agricultural Research., Washington, v. 46, p. 771-779, 1933.

13. Reis. E. M. Perithecial formation of Gibberella zeae on senescent stems of grasses under natural conditions. Fitopatol Brasileira, Brasília, DF,v.15, p. 52-54, 1990.

14. Reis, E. M.; Blum, M.M.C.; Casa. R. T.; Medeiros, C.A. Grain losses caused by infection of wheat heads by Gibberella zeae in southern Brazil, from 1984 to 1994. Summa Phytopathologica, Botucatu, v.22, p.134-137, 1996.

15. Reunião da Comissão Sul-Brasileira de pesquisa de trigo e triticale, 2005, Cruz Alta. Indicações técnicas para a cultura do trigo e triticale: Reunião da Comissão Sul-Brasileira de pesquisa de trigo e triticale - 2005. Cruz Alta: FUNDACEP, 2005.162p.

16. Strange, R.N.; Majer, J.R.; Smith, H. Isolation and identification of choline and betaine as two major components in anthers and wheat-germ that stimulate Fusarium graminearum in vitro. Physiological Plant Pathology, St Paul, v. 4, p. 277-290, 1974.

17. Sutton, J. C. Epidemiology of wheat head blight and maize ear rot caused by Fusarium graminearum. Canadian Journal of Plant Pathology, Ottawa, v.4, n.2, p. 195-209, 1982.

18. Zoldan, S. M. Risk areas, anthesis characterization in winter cereals and warning system to head blight in wheat. Doutorado em fitopatologia. Universidade de Passo Fundo. Passo Fundo, 2008. 